UDC: $159.946 .3-053.4$

DOI: 10.26697/ijes.2019.2.34

\section{Psychological Support for University Lecturers' Professional Self-Fulfilment}

Professor Korniyaka O. M. ${ }^{1}$

${ }^{1}$ Kostiuk Institute of Psychology of the NAPS of Ukraine, Ukraine

\begin{abstract}
Background:

The theses presents the results revealing with performed regression analysis of the determinants of university lecturers' professional self-fulfilment; the main directions, means and forms of self-fulfilment psychological support are outlined on the result basis. Lecturers are the key figures in future professionals' vocational training. They must constantly solve the tasks of "intellectual communication" as a complete and systematic transfer of knowledge from its carriers to future professionals and colleagues-professionals. Thus, implementation by lecturers (as well as any other specialists) of the strategy of self-fulfilment in their profession is determined, firstly, by personal significance of the work performed by them, the need for self-fulfilment as a process and a result of life goal achievement; secondly, readiness for constant selfeducation, professional development, and professional task solving; thirdly, their creative attitude to work, the desire to enrich professional experience, improve methods and means of actions.

Our research purpose is to determine the leading factors of lecturers' professional self-fulfilment and to develop on this basis the psychological support for their professional self-fulfilment.
\end{abstract}

\section{Methods:}

Statistical processing of empirical data with regression analysis has been performed. The obtained results became the basis for development of the psychological support for lecturers' professional self-fulfilment.

\footnotetext{
Results:

According to the empirical study results, communicative factors are the most significant predictors of achievement by university lecturers of high self-fulfilment in their profession. This is due to the specifics of their professional work, carried out in the form of scientific and pedagogical communications. In addition, the statistical analysis of experimental data and the qualitative interpretation of the performed regression analysis have allowed us to determine that the most significant factors for high professional selffulfulment (general, internal professional and external professions) by the studied specialists are the indicator of "creativity in professional communications", which is understood as a manifestation of creativity in the communicative-speech component of the lecturers' professional work.

The performed study has also determine other leading factors of internal and external professional selffulfilment of these specialists.
}

Based on the empirical study results, we identified the main areas of psychological support for the university lecturers' professional self-fulfilment: 1) deepening the content of their own professional work and achieving satisfaction with their work; 2) constant development of internal and external professional motivation; 3) development of value orientations inherent to a selfactualizing personality; strengthening the value attitude to the chosen specialty; 4) development of an individual's creativity and creative-communicative orientations, ensuring constant creative manifestations at professional communications and in own life in general (development creativity and creativecommunicative orientations is emphasized in the forecasts on the upcoming professional changes); 5) intensive development of professional competence and its structural components, such as informational, creative, pedagogical and self-educational ones; 6) improvement of communicative competence as a key component of professional competence with an emphasis on its components: a) motivational, cognitive and instrumental criteria; b) speech competence; c) nonverbal (pedagogical) expressiveness of the lecturers' speech communication; 7) development of sociability as the ability to quickly establish deep and emotionally rich contacts with other people.

Lecturers' self-fulfilment and personal realisation in the chosen profession can be facilitated by the psychological support in the following forms: psychological counselling, thematic conversations, psychological training, revealing communicatively active means that suit a specialist's personality, business games, rationalization of professional tasks through appropriate informing, psychological corrective means, and also measures aimed at good health maintaining and negative personal and professional phenomena preventing.

\section{Conclusions:}

- implementation of all motivational-value, cognitive, communicative, ethical and other features of scientificpedagogical specialists as signs of self-fulfilment is required for such specialists' full functioning;

- in terms of psychological assistance for such specialists' personality development and for creation of opportunities for their professional expression, it is important to use the individual and creative approaches for purposeful formation of important personal traits and professional qualities.

\section{Information about the author:}

Korniyaka Olga Mykolayivna - Doctor of Psychological Sciences, Professor, Leading Researcher of the Laboratory of Age Psychophysiology of Kostiuk Institute of Psychology of the NAPS of Ukraine, Kyiv, Ukraine.

Research interests: psychology of communication, communicative competence, professional and personal self-fulfilment; http://orcid.org/0000-0003-1471-9238.

\section{Corresponding Author:}

Korniyaka Olga Mykolayivna

Corresponding Author's Email:

olga.korniyaka@gmail.com 